\section{Clarifying Taxonomy and Nomenclature of Fothergilla (Hamamelidaceae) Cultivars and Hybrids}

\author{
Thomas G. Ranney ${ }^{1,4}$ and Nathan P. Lynch ${ }^{2}$ \\ Department of Horticultural Science, Mountain Horticultural Crops \\ Research and Extension Center, North Carolina State University, \\ 455 Research Drive, Fletcher, NC 28732-9244
}

Paul R. Fantz ${ }^{1}$

Department of Horticultural Science, North Carolina State University, Raleigh, NC 27695-7609

\section{Paul Cappiello ${ }^{3}$}

Yew Dell Gardens, P.O. Box 1334, 6220 Old LaGrange Road, Crestwood, KY 40014-9550

Additional index words. cytology, DNA content, flow cytometry, Fothergilla gardenii, Fothergilla major, Fothergilla Xintermedia, genome size, hybrid fothergilla, interspecific hybridization, polyploidy, witch-alder

Abstract. Fothergilla L. spp. are valuable nursery and garden plants. However, clear differentiation among $F$. gardenii Murray, $F$. major Lodd., and potential hybrids can be difficult based solely on morphological characteristics. The objectives of this work were to verify and describe the existence of interspecific hybrids and to clarify the proper nomenclature for cultivars of Fothergilla that are commonly grown in the nursery industry. A comparison of morphological characteristics was made among diverse clones representing both species and potential hybrids. A combination of chromosome counts and DNA contents was used to clearly differentiate among $F$. gardenii $(2 n=4 x=48)$, $F$. major $(2 n=6 x=72)$, and hybrids $(2 n=5 x=60)$. It was determined that the majority of cultivars represented in commerce were hybrids. Fothergilla $\times$ intermedia Ranney and Fantz (hybrid fothergilla) is proposed as the name for these hybrids and is validated with a Latin diagnosis. Although certain morphological characteristics can be used to differentiate between $F$. gardenii and $F$. major, the hybrids tend to be intermediate and are particularly difficult to separate from $F$. major on the basis of appearance. The correct classification and nomenclature for 17 different taxa are presented.

Fothergilla L. spp. (fothergilla or witchalder; Hamamelidaceae R. Brown) are exceptional garden plants (Clark, 1987; Dirr, 1998; Flint, 1984; Weaver, 1971) that display showy, white, fragrant flowers in a terminal spike that resembles a bottlebrush. Summer foliage color can be dark green to blue-green

Received for publication 15 Nov. 2006. Accepted for publication 30 Dec. 2006.

This research was funded, in part, by the North Carolina Agricultural Research Service, Raleigh, NC 27695-7643, and the North Carolina Association of Nurserymen, Raleigh, NC 27607-4904.

The authors gratefully acknowledge the excellent technical assistance of Tom Eaker and Joel Mowrey at the Mountain Horticultural Crops Research and Extension Center, the staff at the Mountain Horticultural Crops Research Station, and Cassandra Finger and JoAnne Fischer at Yew Dell Gardens. ${ }^{1}$ Professor.

${ }^{2}$ Research specialist.

${ }^{3}$ Executive Director.

${ }^{4}$ To whom reprint requests should be addressed; e-mail tom_ranney@ncsu.edu. wide and from 0.9 to $1.5 \mathrm{~mm}$ deep. Cytology determined a chromosome number of $2 n=$ $4 x=48$ (Weaver, Jr., 1969). In contrast, $F$. major is found on upland sites in the piedmont and mountains of North Carolina, South Carolina, Georgia, Alabama, Tennessee, and Arkansas (Flora of North America Editorial Committee, 1993+; Weakley, 2006; Weaver, Jr., 1969). This species generally is larger in stature $(7-65 \mathrm{dm})$ than $F$. gardenii and is distinguished by larger leaves ranging from 2.5 to $13 \mathrm{~cm}$ long and 4.2 to $12.5 \mathrm{~cm}$ wide that generally are toothed from below the middle and conspicuously asymmetric at the base. Stipules are 2.8-7 (10.2) $\mathrm{mm}$ long. Stamens generally number (18) 22-32. The hypanthium at anthesis ranges from 2.4 to $3.9 \mathrm{~mm}$ wide and from 1.5 to $3 \mathrm{~mm}$ deep. Cytology determined a chromosome number of $2 n=6 x=72$ (Weaver, Jr., 1969). Although there is no known diploid species of fothergilla, Parrotiopsis (Niedenzu) C. Schneid. is a closely allied genus with $2 n=2 x=24$ (Goldblatt and Endress, 1977; $\mathrm{Li}$ and Bogle, 2001; Weaver, Jr., 1969) and may represent a parallel lineage from an ancestral diploid.

Often, the two species of Fothergilla are confused, but they can be separated by comparing key characteristics (Clark, 1988). Also, there has been speculation that the two species of Fothergilla hybridize (Dirr, 1998). Hybrids between these species should have a chromosome number of $2 n=$ $5 x=60$. Microscopic determination of chromosome numbers is not a practical approach for separating species and hybrids among large numbers of cultivars. However, flow cytometry can provide a fast and accurate determination of nuclear DNA content that is related directly to ploidy level (among closely related taxa) and can be used as a taxonomic tool (de Laat et al., 1987; Doležel, 1991; Doležel et al., 1998; Galbraith et al., 1983).

The objectives of this research were to verify the existence of hybrids between $F$. gardenii and $F$. major and to clarify the proper taxa designations for clones of Fothergilla commonly grown in the nursery industry.

\section{Materials and Methods}

Plant material and morphology. Collections of Fothergilla at the North Carolina State University, Mountain Horticultural Crops Research and Extension Center, Fletcher, N.C. (NCSU) and Yew Dell Gardens, Crestwood, Ky. (YDG), were used for this project (Table 1). Morphological measurements were taken on lamina length, lamina width, leaf margin dentation location (strictly above the middle, to the middle, or extending to below the middle), symmetry of leaf base (symmetrical, variable, or asymmetrical), stipule length, stamen number, and hypanthium depth and width at anthesis. Twelve measurements were taken for each leaf morphology character, and six measurements were taken for each flower morphology character for each clone. 


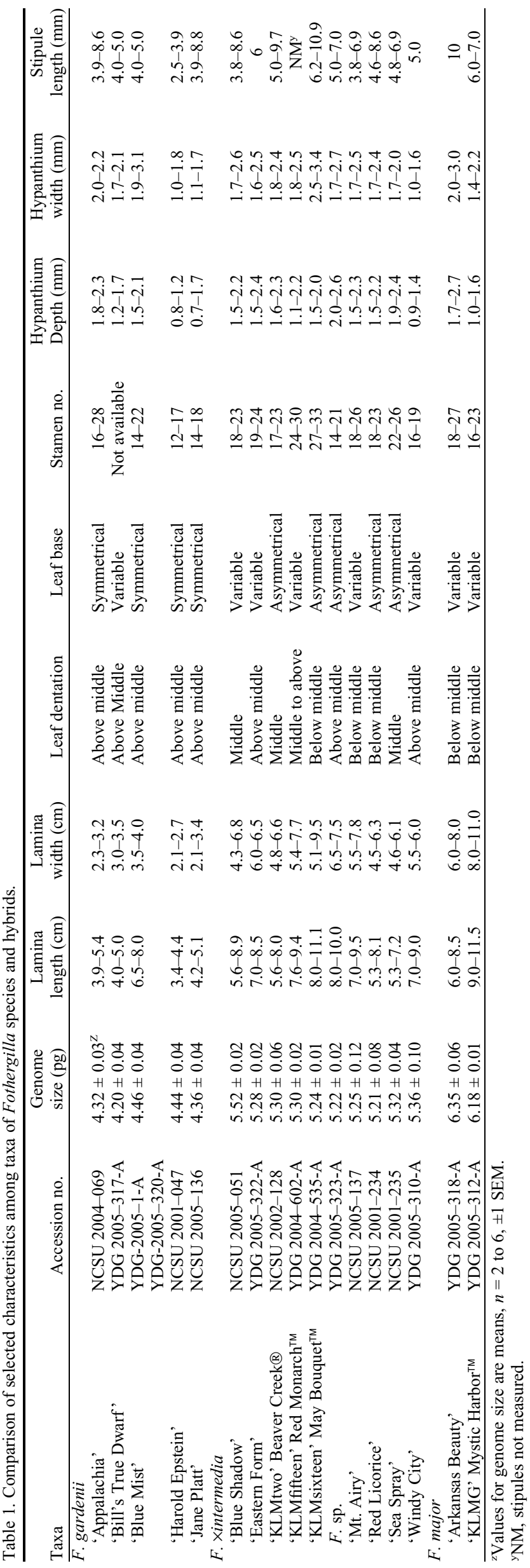

Flow cytometry. Holoploid, 2C DNA contents (i.e., DNA content of the entire nonreplicated, chromosome complement irrespective of ploidy level) were determined via flow cytometry (de Laat et al., 1987; Doležel, 1991; Galbraith et al., 1983; Greilhuber et al., 2005). Nuclei isolation and staining followed protocols provided by Partec $\mathrm{GmbH}$ (Münster, Germany). About 12 stamen filaments were chopped with a razor blade in a petri dish containing $400 \mu \mathrm{L}$ of extraction buffer (CyStain ultraviolet Precise P, Partec). The suspension was filtered through $50-\mu \mathrm{m}$ nylon mesh, and nuclei were stained using $1.6 \mathrm{~mL}$ of staining buffer containing $4^{\prime}, 6-$ diamidino-2-phenylindole (DAPI) (CyStain ultraviolet Precise P, Partec). The suspension was analyzed using a flow cytometer with fluorescence excitation provided by a mercury arc lamp (PA-I Ploidy Analyzer, Partec). The mean fluorescence of each sample was compared with an internal standard of known genome size (Pisum sativum L. 'Ctirad', 2C $=9.09$ pg; Doležel et al., 1998). A minimum of 4,500 nuclei were analyzed to calculate the ratio of sample peak to the internal standard for determining genome size $[2 \mathrm{C} \mathrm{pg}=$ (mean fluorescence of sample peak/mean fluorescence of internal standard peak) $\times 9.09 \mathrm{pg}$ ]. Two to six subsamples were analyzed for each taxa.

Chromosome counts. Root tips were collected in the morning from newly rooted stem cuttings of Fothergilla 'Mt. Airy' and placed in $2 \mathrm{mM}$ 8-hydroxyquioline for $3-5 \mathrm{~h}$ at $12{ }^{\circ} \mathrm{C}$. Roots were then rinsed with cold $\left(4{ }^{\circ} \mathrm{C}\right)$ distilled water and placed in $3: 1$ solution of $95 \%$ ethanol/propionic acid fixative for $\approx 24 \mathrm{~h}$ at room temperature. Samples were rinsed with cold distilled water, transferred to a $70 \%$ ethanol storage solution, and placed in a refrigerator at $4{ }^{\circ} \mathrm{C}$. The following week, samples were removed from storage and transferred to $30 \%$ aqueous ethanol for $12 \mathrm{~min}$, followed by two 15 -min rinses in distilled water. Roots were then hydrolyzed for $30 \mathrm{~min}$ at room temperature in $1 \mathrm{~N} \mathrm{HCl}$ and then for $15 \mathrm{~min}$ at $60{ }^{\circ} \mathrm{C}$, followed by a quick rinse in distilled $\mathrm{H}_{2} \mathrm{O}$. Small samples of root tips were excised and placed on a glass microscope slide with a drop of $1 \%$ acetocarmine stain, squashed with a coverslip, and viewed at $1500 \times$.

\section{Results and Discussion}

Cytological examination of 14 mitotic cells revealed that Fothergilla 'Mt. Airy' was a pentaploid with $2 n=5 x=60$ (Fig. 1), thereby confirming that it is a hybrid between tetraploid $F$. gardenii and hexaploid $F$. major . Flow cytometry was an effective method for determining genome size and ploidy levels of the species and their hybrids (Fig. 2). Fothergilla 'Mt. Airy', a confirmed pentaploid, was used as a reference to compare the approximate genome sizes (DNA content) for the different ploidy levels. Mean 2C holoploid genome sizes for $F$. gardenii ranged from 4.2 to $4.5 \mathrm{pg}$, hybrids ranged from 5.2 to $5.5 \mathrm{pg}$, and $F$. major ranged from 6.2 to $6.4 \mathrm{pg}$ 


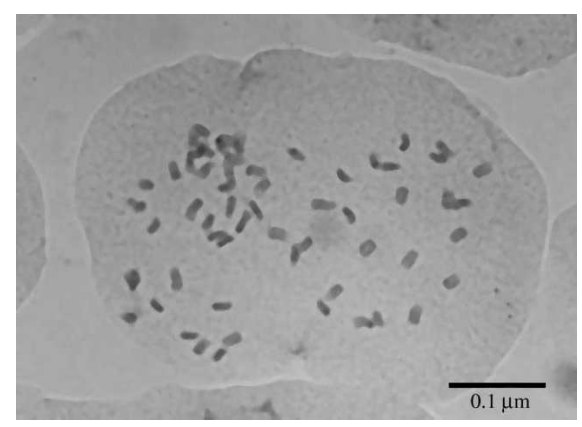

Fig. 1. Photomicrograph of root tip cell of Fothergilla $\times$ intermedia 'Mt. Airy' in prophase with 60 somatic chromosomes.

(Tables 1 and 2). Genome sizes within species and hybrids had a narrow range, providing clear distinction between the three taxonomic groups consistent with variations in ploidy levels. Mean $1 \mathrm{C} x$ monoploid genome size (i.e., DNA content of one nonreplicated base set of chromosomes with $x=12$ ) was similar at $1.09 \mathrm{pg}$ DNA for $F$. gardenii, $1.06 \mathrm{pg}$ DNA for the hybrids, and $1.04 \mathrm{pg}$ DNA for $F$. major, indicating that monoploid genome size is highly conserved among species and ploidy level in Fothergilla.

Differentiation between species was often ambiguous based on foliar and floral characteristics (Tables 1 and 2). Ranges for lamina length, stipule length, and hypanthium depth and width tended to overlap between these two species. Due to considerable variation within species and overlap in ranges between species in our sample set, leaf margin dentation, symmetry of the leaf base, and stamen number provided little value for separating these two species. Lamina width was the only characteristic, with distinct ranges from 2.1 to $4.0 \mathrm{~cm}$ for $F$. gardenii and from 6.0 to $11.0 \mathrm{~cm}$ for $F$. major. Although we did not compare plant height and emergence of flowers relative to foliage, it was reported generally that $F$. gardenii had a smaller mature height and bloomed before leaf emergence, while $F$. major had a larger mature height and bloomed with the emergence of new foliage (Clark, 1988; Weaver, Jr., 1969).

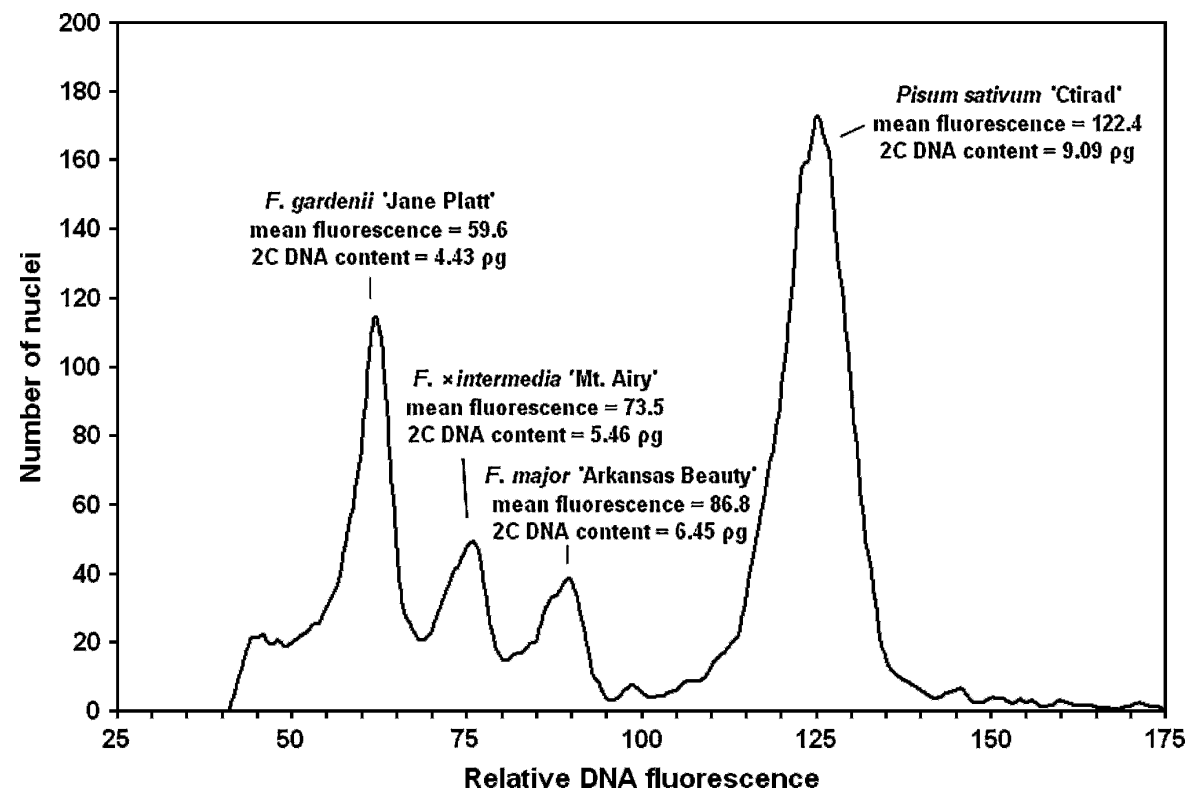

Fig. 2. Flow cytometry histogram of a combined sample containing nuclei from $F$. gardenii 'Jane Platt' $(2 n=4 x=48), F$. Xintermedia 'Mt. Airy' $(2 n=5 x=60), F$. major 'Arkansas Beauty' $(2 n=6 x=72)$, and an internal standard, Pisum sativum 'Ctirad', with a known $2 \mathrm{C}$ holoploid DNA content of $9.09 \mathrm{pg}$. The DNA contents of Fothergilla samples were calculated based on mean sample fluorescence relative to the internal standard.

Separating hybrids from parental species was particularly challenging when based strictly on morphology. Most ranges for morphological measurements of hybrids overlapped with one or the other parent (Table 2). One exception was that the lamina width of $F$. gardenii was consistently narrower than either $F$. major or the hybrids. In general, hybrids tended to resemble $F$. major more closely, likely resulting from higher ploidy level and gene dose that was contributed from $F$. major.

To help clarify the taxonomy and nomenclature of Fothergilla spp., nothospecies $F$. Xintermedia Ranney and Fantz is proposed for the hybrid species name in accordance with Article H.3-5 (Greuter et al., 2000). The new hybrid species is described as follows: Nothospecies Fothergilla Xintermedia Ranney and Fantz hybrida nova a F. gardenii Murray et
F. major Lodd. cum characteribus morphologica intermedius, tamen distinguibili cytologia ambospecies pentaploidis cum chromosomatum $2 n=60$, et genomibus amplitude 5.2-5.5 pg DNA, et distinguibili latofolius ad F. gardenia et folius dentibus ad super vs. infra medium ad $F$. major. Pentaploid hybrid shrub, $2 n=60$ with genome size of 5.2 5.5 pg DNA. Leaf blade, $5.3-11.1 \mathrm{~cm}$ long, $4.3-7.8(9.5) \mathrm{cm}$ wide, base asymmetrical or variable, margins toothed from above the middle to below the middle; stipules, 3.8$10.9 \mathrm{~cm}$ long. Fruit and seed typically lacking. Flowers with hypanthium, 0.9-2.6 mm wide and 1.0-3.4 mm deep; stamens, 14 30 in number. Holotype: Fothergilla 'Mt. Airy', plant, $1.5 \mathrm{~m}$ tall, NCSU 2006-137, Mountain Horticultural Crops Research Station, Fletcher N.C., 25 Sept. 2006, Fantz and Ranney 8911 (NCSC). Isotype: NA.

Table 2. Comparison of characteristics of Fothergilla gardenii, F. Xintermedia, and F. major.

\begin{tabular}{|c|c|c|c|}
\hline Characteristic & F. gardenii & F. $\times$ intermedia & F. major \\
\hline \multicolumn{4}{|l|}{ Chromosomes } \\
\hline Chromosome no. ${ }^{\mathrm{z}}$ & $2 n=4 x=48$ & $2 n=5 x=60$ & $2 n=6 x=72$ \\
\hline Genome size $(2 C)^{y}$ & $4.2-4.5 \rho g$ DNA & $5.2-5.5 \rho g$ DNA & $6.2-6.4 \rho g$ DNA \\
\hline \multicolumn{4}{|l|}{ Leaves } \\
\hline Lamina length $(\mathrm{cm})$ & $3.4-5.4(8)^{x}$ & $5.3-11.1$ & $6.0-11.5$ \\
\hline Lamina width $(\mathrm{cm})$ & $2.1-4.0$ & $4.3-7.8(9.5)$ & $6.0-11.0$ \\
\hline Leaf dentation location & $\begin{array}{l}\text { Mostly toothed } \\
\text { above the middle }\end{array}$ & $\begin{array}{l}\text { Toothed above, interm., or } \\
\text { below the middle }\end{array}$ & $\begin{array}{l}\text { Toothed from } \\
\text { below the middle }\end{array}$ \\
\hline Leaf base & Symmetrical or variable & Asymmetrical or variable & Variable \\
\hline Stipule length & $3.9-8.8$ & $3.8-10.9$ & $6.0-10.0$ \\
\hline \multicolumn{4}{|l|}{ Flowers } \\
\hline Stamen no. & $12-28$ & $14-30$ & $16-27$ \\
\hline Hypanthium depth (mm) & $0.7-2.3$ & $0.9-2.6$ & $1.0-2.7$ \\
\hline Hypanthium width (mm) & $1.0-2.2$ & $1.0-3.4$ & $1.4-3.0$ \\
\hline
\end{tabular}

${ }^{\mathrm{z}}$ Chromosome numbers for $F$. gardenii and $F$. major were determined by Weaver, Jr. (1969).

${ }^{y}$ Ranges for cytometry and morphological traits are a compilation of data from Table 1 .

${ }^{\mathrm{x}}$ Numbers in parentheses indicate extreme ranges, but uncommon occurrences. 
On the basis of this study, we further identified the cultivars 'Appalachia', 'Bill's True Dwarf', 'Blue Mist', 'Harold Epstein', and 'Jane Platt' as F. gardenii. Cultivars 'Arkansas Beauty' and 'KLMG' Mystic Harbor were found to be $F$. major. The remaining cultivars, representing the majority of named selections in commerce, including 'Blue Shadow', 'Eastern Form', 'KLMtwo' Beaver Creek, one unnamed clone (YDG 2005-323A), 'KLMfifteen' Red Monarch, 'KLMsixteen' May Bouquet, 'Mt. Airy', 'Red Licorice', 'Sea Spray', and 'Windy City' were hybrids, F. Xintermedia.

\section{Literature Cited}

Clark, R.C. 1987. Another southern delight: the witch alders (Fothergilla spp.). Morton Arboretum Qrtly. 23(3):33-39.

Clark, R.C. 1988. A case of mistaken identity: how to correctly identify Fothergilla. Amer. Nurseryman 168(4):52-54, 58-59.

de Laat, A.M.M., W. Göhde, and M.J.D.C. Vogelzang. 1987. Determination of ploidy of single plants and plant populations by flow cytometry. Plant Breed. 99:303-307.
Dirr, M.A. 1998. Manual of woody landscape plants: their identification, ornamental characteristics, culture, propagation and uses. 5th ed. Stipes Publishing, Champaign, Ill.

Doležel, J. 1991. Flow cytometric analysis of nuclear DNA content in higher plants. Phytochem. Anal. 2:143-154.

Doležel, J., J. Greilhuber, S. Lucretti, A. Meister, M.A. Lysák, L. Nardi, and R. Obermayer. 1998. Plant genome size estimation by flow cytometry: inter-laboratory comparison. Ann. Bot. (Lond.) 82:17-26.

Flint, H. 1984. Fothergilla. Horticulture 63(9): $12-16$.

Flora of North America Editorial Committee. 1993+ Flora of North America North of Mexico, Vol. 3, Magnoliophyta: Magnoliidae and Hamamelidae. Oxford Univ. Press, New York. 25 Aug. 2006. <http://www.efloras.org/ florataxon.aspx?flora_id=1\&taxon_id=112962>

Galbraith, D.W., K.R. Harkins, J.M. Maddox, N.M. Ayres, D.P. Sharma, and E. Firoozabady. 1983. Rapid flow cytometric analysis of the cell cycle in intact plant tissues. Science 220:1049-1051.

Goldblatt, P. and P.K. Endress. 1977. Cytology and evolution in Hamamelidaceae. J. Arnold Arboretum 58:67-71.
Greilhuber, J., J. Doležel, M.A. Lysák, and M.D. Bennett. 2005. The origin, evolution and proposed stabilization of the terms "genome size" and "C-value" to describe nuclear DNA contents. Annal Bot. 95:255-260.

Greuter, W., J. McNeill, F.R. Barrie, H.M. Burdet, V. Demoulin, T.S. Filgueiras, D.H. Nicholson, P.C. Silva, J.E. Skog, P. Trehane, N.J. Turland, and D.L. Hawksworth. 2000. International Code of Botanical Nomenclature (Saint Louis Code). Költz Sci. Books, Königstein, Germany.

Li, J. and A.L. Bogle. 2001. A new suprageneric classification system of the Hamamelidoideae based on morphology and sequences of nuclear and chloroplast DNA. Harv. Pap. Bot. 5(2): 499-515.

Weakley, A.S. 2006. Flora of the Carolinas, Virginia, and Georgia, and Surrounding Areas UNC Herbarium, N.C. Botanical Garden, Univ. of N.C., Chapel Hill. 25 Aug. 2006. <http://www.herbarium.unc.edu/ flora.htm>

Weaver, R.E. 1971. The Fothergillas. Arnoldia 31(3):89-97.

Weaver, Jr., R.E. 1969. Studies in the North American genus Fothergilla (Hamamelidaceae). J. Arnold Arboretum 50(4):599-619. 